\title{
Action and Agency in the Criminal Law
}

\author{
Vincent Chiao
}

Version Post-print/accepted manuscript

Citation Vincent Chiao, "Action and Agency in the Criminal Law," (2009) 15

(published version) Legal Theory 1.

Publisher's Statement This is the peer reviewed version of the article: Vincent Chiao, "Action and Agency in the Criminal Law," (2009) 15 Legal Theory 1. Copyright (C) [2009]. Reprinted by permission of the Harvard Law Review Forum. The final version can be found at https://doi.org/10.1017/S135232520909003X

How to cite TSpace items

Always cite the published version, so the author(s) will receive recognition through services that track citation counts, e.g. Scopus. If you need to cite the page number of the author manuscript from TSpace because you cannot access the published version, then cite the TSpace version in addition to the published version using the permanent URI (handle) found on the record page.

This article was made openly accessible by $U$ of 'T Faculty. Please tell us how this access benefits you. Your story matters. 


\section{Action and agency in the criminal law. ${ }^{1}$}

In 1960, H.LA. Hart published a paper entitled “Acts of Will and Responsibility," in which he challenged the traditional understanding of the "voluntary act requirement" in Anglo-American criminal law theory. ${ }^{2}$ The traditional understanding, Hart contended, had never provided a very satisfactory account of what it took to qualify as a "voluntary act." Hart wrote that he could not "find in any legal writings any clear or credible account of what it is for conduct to be voluntary and not involuntary in the sense required." It was dubious that the courts actually relied on any general doctrine of voluntariness and it was in any case not clear that a positive account of voluntary action was actually necessary for what the theorists wanted the so-called "voluntary act requirement" to do. ${ }^{3}$ Despite Hart's criticisms, however, the traditional understanding of voluntary action has endured in both legal theory and legal doctrine. ${ }^{4}$

${ }^{1}$ In writing this paper, I have greatly benefited from comments and criticism by anonymous readers at Legal Theory, Mitch Berman, John Deigh, Joshua Dressler, Douglas Husak, Daryl Levinson, Ken Levy, Bill Stuntz and participants at workshops at Harvard Law School and at the University of Texas School of Law.

${ }^{2}$ In The Jubilee Lectures of the Faculty of Law, University of Sheffield, ed. O.R. Marshall (Stevens \& Sons, 1960), later reprinted in Punishment and Responsibility (Oxford: Oxford University Press, 1968).

Citations are to the reprinted edition.

3 “Acts of Will and Responsibility," p.90.

${ }^{4}$ In legal theory, see Michael Moore, Act and Crime: the Philosophy of Action and its Implications for Criminal Law (Oxford: Oxford University Press, 1993); in legal doctrine, see Model Penal Code $\$ 2.01$. 
The persistence of the view that criminal responsibility requires an act, as well as its methodological corollary that legal theory requires a theory of action, is somewhat puzzling as the view faces apparently intractable flaws. Recently, skepticism has been growing, and a number of authors have pointed out some of the difficulties that plague both the doctrinal view as well as criminal theory's philosophical interpretation of action. ${ }^{5}$ In this paper, I join the skeptics, but seek to go further in reconstructing the intuition that I believe motivates the act requirement, and which may help explain the doctrine’s otherwise puzzling persistence. In brief, I defend the following propositions in this paper: first, that orthodox Anglo-American criminal theory (as represented by Michael Moore's updating of Austin's volitionalism) fails to adequately explain why criminal responsibility requires an act. Second, when it comes to the just definition of crimes, the act requirement is at best a rough generalization rather than a substantive limiting principle. Third, that what is sound in the intuition underlying the so-called "act requirement" is better explained by what I call the "practical agency condition," according to which punishment in a specific instance is unjust unless the crime charged was caused or constituted by the agent's conduct (broadly understood) qua practically rational agent. I argue that the practical agency condition embodies what is worth retaining in Anglo-American criminal law's notion of an "act requirement."

${ }^{5}$ See Douglas Husak, The Philosophy of Criminal Law, ch. 4 (New Jersey: Rowman \& Littlefield, 1987); "Does Criminal Liability Require an Act?", in R.A. Duff, ed. Philosophy and the Criminal Law (Cambridge: Cambridge University Press, 1998), pp.60-100; and "Rethinking the Act Requirement," 28 Cardozo.L.R. 2437 (2007). See also Antony Duff, in "Action, the Act Requirement and Criminal Liability," in J. Hyman and H.C. Steward, eds., Agency and Action (Cambridge: Cambridge University Press, 2004), P.F. Fitzgerald, "Voluntary and Involuntary Acts," in A.G. Guest, ed., Oxford Essays in Jurisprudence (Oxford: Oxford University Press, 1961) and A.P. Simester, "On the So-called Requirement for Voluntary Action,” 1 Buff.Crim.L.Rev. 403 (1998). 


\section{1.}

Anglo-American criminal theory has inherited a philosophical account of action that stems from Austin's Lectures, though it has roots going back at least to Hobbes. ${ }^{6}$ According to this line of thought, a human action is a bodily movement (sometimes a "muscular contraction") caused by a type of mental state called a "volition." The difference, in other words, between my arm moving and my moving of my arm is that in the latter case the movement is caused by a volition-a determination of the will—whereas in the former case, the movement could be nothing more than

${ }^{6}$ See Austin's Lectures on Jurisprudence, R. Campbell, ed. (London: John Murray, 1879), Lecture XVIII, p.429. I do not mean to say that existing criminal codes embody, explicitly or implicitly, a specific philosophical account of action. For instance, the Model Penal Code declines to define what is meant by the "voluntary act or omission" required for liability, and proceeds by listing conditionsconvulsion, unconsciousness, etc.—which, if proven, negate voluntary action. See MPC \$2.01(1) and (2). However, the challenge posed by this doctrinal structure is (a) to say more explicitly what unifies the various kinds of defeating conditions, and (b) to explain why the law should require voluntary action (however defined) in the first place. To the degree Anglo-American criminal theorists have taken up this task, they have traditionally done so by appeal to an account of voluntary action as willed bodily movement.

${ }^{7}$ Lectures on Jurisprudence, pp.424-5. This picture has extreme difficulty in actually getting the phenomenon of agency into view. Holmes is an instructive instance, e.g. when he writes that there is a "mysterious accuracy with which the adult, who is master of himself, foresees the outward adjustment which will follow his inward effort." The Common Law, S.M. Novick, ed. (New York: Dover Publications, 1991), p.54. 
the result of being pushed. The propositional object of a volition was taken to be merely "that my body move thus-and-so" or "that this muscle contract this far," and specifically not "that I shoot A," or "that I open the door." Holmes picked up this Austinian line of thought when he suggested that all that it takes to satisfy the act requirement is that the agent have willed a muscular contraction, and that the agent need not have conceived of the muscular contraction as an instance of a particular type of action, as taking place in a certain context, or as having any particular consequences whatsoever. All of those features were to be considered circumstances and consequences, and they figured into responsibility only insofar as the "reasonable man" should have known that the circumstances were as they were, and that contracting his muscles or moving his limbs in those circumstances would have those consequences. ${ }^{8}$

Postulating an act requirement so defined thus resolves two issues in legal theory in one fell swoop: first, it explains at least some of the exemptions from responsibility recognized at law (unconsciousness, seizure, physical coercion), and second, it explains why Anglo-American law has been hesitant to consider omissions, thoughts and statuses as proper objects of criminal regulation. This is done by appeal to a metaphysical picture of action. Defining actions in this manner thus had several advantages for a theorist interested in systematizing criminal law. Notably, it provided a unified view of criminal liability from what can be called both the legislative and judicial points of view: a statute that purports to criminalize something other than a willed bodily movement is unjust, as is a judicial proceeding that punishes a person for something other than willed bodily movement, even if the applicable statute is facially just. ${ }^{9}$

\footnotetext{
${ }^{8}$ See Holmes, The Common Law, lecture 2.

${ }^{9}$ The tendency to run together what the legislative and judicial functions of the act requirement is evident, for instance, in James Fitzjames Stephen's claim that "the general definition of crimes is that they are actions punished by law. Certain qualities are or are supposed to be common to all actions
} 
But why define actions in terms of willed bodily movement? Because, I suspect, doing so allowed the theorist to then assign a clear role to mens rea doctrine: acts describe what can possibly be criminalized in the first place, and mens rea standards describe which acts in fact are criminalized. Since the degree, and kind, of fault required differs in different cases-negligently dropping a brick from a rooftop and intentionally releasing a brick with intent to kill are both possible objects of criminal liability_focusing on willed bodily movement seems promising as one thing every crime would have in common. ${ }^{10}$ Beliefs regarding circumstances and consequences, motives and the like are relevant in selecting which cases from this set are actually to be punished. This suggests that determining for legal purposes whether a person has "acted" is morally neutral, in the sense that it does not presuppose a moral assessment of the agent or the act. Where moral and legal assessment starts is with the standards applied to the awareness of consequences, circumstances and motivations which the law punishes, and the existence of those qualities in the particular case is a necessary condition of criminality." General View of the Criminal Law of England (London: Macmillan, 1863), p.75. It is, in my view, the failure to sufficiently distinguish these two roles which explains much of the confusion still surrounding the act requirement.

${ }^{10}$ It is possible — though sheer speculation on my part — that the generalization would have seemed more plausible to theorists of Austin's general era because of the rather more limited scope of criminalization at that period, focusing on crimes such as murder, rape, arson and so forth, each of which not only typically requires, but is essentially concerned with willed bodily movement. In contrast, contemporary substantive doctrine includes crimes of possession, regulatory offenses, and wide-ranging group conspiracy crimes, where even if an act is "included" as an element of the crime, it is far from obvious that the act is the object of punishment. These developments in the criminal law may contribute to making the act requirement seem much more questionable now than it perhaps once was. (I owe this suggestion to Bill Stuntz.) 
present in the agent's psychological set at the time of the action. In other words, to say that A acted is not itself to assign responsibility to A; the attribution of the resulting harm to the agent only arises when the act is described as accompanied by, say, negligence or criminal intent. ${ }^{11}$ Something along these lines is, I take it, what Holmes had in mind when he described acts as "indifferent."

Were it not for Michael Moore's exhaustive rehabilitation of the willed bodily movement account of action, Austin and Holmes' remarks might today be mainly of antiquarian interest. ${ }^{12}$ However, in Act and Crime - the most systematic and detailed account of the concept of action in the criminal law currently available-Moore undertakes an ambitious re-articulation and defense of the classical account of action, arguing both for its independent philosophical plausibility as well as its centrality to notions of criminal responsibility. ${ }^{13}$ There, Moore claims that his "functionalist" reinterpretation of the willed bodily movement view “defuses” Hart's principle objection to Austin’s

${ }^{11}$ The Common Law, p.75. My thanks to an anonymous referee for pushing me to clarify this point. ${ }^{12}$ Jeffrie Murphy, writing nearly forty years ago, described Austin's theory and commented that, “to those whose philosophical nurturing is post-Wittgensteinian, these assertions will seem strange. We seem to have a paradigm here of that metaphysical idiocy which is politely called 'dualistic interactionism' and has been called by Gilbert Ryle (not so politely) 'the dogma of the Ghost in the Machine.' The picture conjured up is of a spiritual mind pulling (in some causally mysterious way) the levers which run the body...If made with respect to a master sculptor or ballet dancer, this has some sense. But with respect to ordinary actions, this sort of remark now strikes us as just extremely funny." "Involuntary Acts and Criminal Liability," 81 Ethics 332, 334 (1971). (To be fair, Murphy goes on to defend what he considers "a form of the classical theory" against Hart's criticisms.) ${ }^{13}$ See also Kevin Saunders, "Voluntary Acts and the Criminal Law: Justifying Culpability Based on the Existence of Volition," 49 U.Pitt.L.Rev. 443 (1988). 
account, thereby vindicating Austin and orthodox criminal theory. ${ }^{14}$ I now turn to consider Moore's argument.

Hart had claimed that, contrary to what Austin's account would lead one to expect, we in fact are not generally aware of ourselves as willing discrete muscular contractions, or even movements of our limbs as such. Rather, our conscious and deliberative activity is directed to the things we do by moving our bodies: saying "hello," for instance, rather than moving one's lips, taking the purse rather than contracting fingers. To be sure, under particular circumstances, we can and do focus our attention and reflection on our limbs and muscular contractions-for example, if I am learning to correctly pronounce the French "r," learning how to play a difficult piano passage, or striving to correct defects in my butterfly stroke. But by and large, Hart wrote,

the simple but important truth is that when we deliberate and think about actions, we do so not in terms of muscular movements but in the ordinary terminology of actions. Of course muscular movements are involved in all such actions; but that does not show either that we are aware of them before acting or that we have a desire for them. ${ }^{15}$

Therefore the characterization of an agent as necessarily willing bodily movement or muscular contraction "is a fatal defect in any account of action supposed to help us to characterize the mental conditions required for the ordinary man's responsibility." 16

\footnotetext{
${ }^{14}$ A functionalist interpretation of volitionalism "defuse[s] some large-scale objections to volitions in post Second World War philosophy. As we shall see... a functional view of volitions cuts the grounds from under several large objections that convinced an entire generation of philosophers (and two generations of legal theorists) to have no truck with volitions, or 'mysterious acts of will."' (Act and Crime, p.132)

15 “Acts of Will and Responsibility,” p.102.

16 “Acts of Will and Responsibility," p.101.
} 
In response, Moore claims that Hart's objection gets no traction against a functionalist interpretation of Austin. Moore agrees with Austin that the difference between bodily movements which are and are not actions lies in their causal histories: actions are those movements which are caused by a particular type of mental state, namely volitions. Volitions are a type of bare intention, whose content concerns nothing but bodily movements. But the fact that we do not normally deliberate about, form intentions regarding, or generally have attitudes toward muscular contractions does not show that there are no volitions; it just means that volitions should not be understood as (conscious) intentional states, but as functionally defined mediators between intentional states (beliefs and desires, for instance) and bodily movements. A functionalist in this sense can be noncommittal about how those mediating volitions are realized, as conscious phenomena, brain states or anything else. As Moore notes, the nature of functional states "is given by their functional roles and not by their accessibility to consciousness. If one has good theoretical reasons to hypothesize a state that mediates between our general preferences and our particular actions, the lack of phenomenological evidence will not be critical." ${ }^{17}$ Volitions thus understood bear no intrinsic connection to "phenomenology" or deliberative awareness: we need no more be aware of volitions, functionally construed, than we are of the sub-atomic particles our bodies are made of, or the Freudian id and superego that play functional roles in our cognitive and emotional lives. Therefore, Moore concludes, Hart's objection that volitions do not enter into deliberative awareness falls wide of the mark.

Has Moore vindicated Austin? I agree with Moore that it is no objection to his account that the volitions it postulates form no part of a person's ordinary deliberative activity. What is an objection, however, is that his functionalist account has severed the connection that made the theory seem relevant to legal and moral responsibility in the first place. For it is quite obscure what the normative ${ }^{17}$ Act and Crime, pp.161-2. 
consequences of the presence or absence of volition, functionally understood as mediating between attitudes and bodily movements, are supposed to be for how we assess a person's responsibility. As phenomena that do not have a role in the deliberative economy, volitions are essentially subpersonal states, mental states or events which may be part of the machinery involved in executing intentions, plans and so forth (e.g., as proximate cause of certain muscular contractions.) But they do not themselves constitute ordinary intentions, plans or the like; they are not, for instance, reasons or desires, attitudes which are generally concerned with objects and goals, not "muscular contractions" as such. But since responsibility and blame are generally assessed at the personal level—such as whether the agent engaged in the questionable conduct intentionally or because an intervening external force caused him to do it-even if we assume that whenever there is action there is volition, that alone would not show that volitions have any bearing on the theory of responsibility. A person who is exempted on grounds of not having acted is not exempted because of a lack of volition, but because his conduct was not suitably attributable to him as an agent. It is more plausible that the spasms, reflexes and the like that exempt an agent from liability do so because they show the conduct in question to be radically unhinged from the agent's deliberative attitudes and capacities, not because they did not volitionally cause the bodily movements, even if the latter is also true. In short, to the degree that Moore's functionalism rescues him from Hart's objection, it renders the theory inert as far as normative theory — an enterprise concerned with explaining and justifying holding people responsible for various things under various circumstances-is concerned. We may still insist on the moral salience of a person acting in certain ways, but the willed bodily movement theory does not capture what we want when we think that acts are more deserving of punishment than non-acts, since our resentment in the case of the agent is directed toward his identification or involvement with his bodily movement, and not toward the existence of sub-personal mental states, functionally specified as occupying a certain position in the causal chain preceding the movement. 
I should be clear that I am not claiming that criminal responsibility must always presuppose some conscious state of mind such as a plan or intention. If strict criminal liability or even criminal negligence is ever just, then that proposition must be false; for such agents need have nothing in mind when they do what they do-indeed, that is often precisely the problem with the negligent actor. ${ }^{18}$ Rather, my claim is that whatever plausibility there is to the view that "was X an act?" is a threshold question to any further inquiry into criminal guilt rests on the view that people are not responsible for bodily movements which are not actions; and the plausibility of this view is, I think, bolstered by the thought that non-action bodily movements are bodily movements that are not connected in the appropriate manner to the individual's deliberative capacities. But once we draw the distinction between action and non-action in terms of functional rather than intentional volitions, that latter connection is severed. ${ }^{19}$

The argument can be made in the form of a dilemma. If we construe volitions as necessarily characterizing an agent's conscious self-control (Austin describes volitions in terms of "my wish of ${ }^{18}$ As Meir Dan-Cohen notes, "the practical significance" of considering voluntariness to be an investigation of actus reus and not mens rea is that involuntary acts will escape even strict liability offenses that do not require showing mens rea." "Actus Reus," in Encyclopedia of Crime and Justice, S. Kadish, ed. (London: Macmillan, 1983), p.18.

${ }^{19}$ An alternative would be to define volitions as those things which most proximately cause bodily movements intentionally described from the agent's point of view. While not incoherent, such a view is about as informative as the view that opium causes sleepiness because it has a dormitive power: volitions cause actions because they are the things that proximately cause whatever it is people take themselves to be doing. (Saunders comes, I think, perilously close to saying just this. See "Voluntary Acts and the Criminal Law: Justifying Culpability Based on the Existence of Volition," 49 U.Pitt.L.Rev. 443, 456ff.. (1988).) 
the movement"), then there is some intuitive appeal to the thought that the epileptic and unconscious agents are excused because they lacked volitional self-control in the relevant sense. ${ }^{20}$ But the Austinian view faces Hart's original objection that it is not true that volitions necessarily characterize an agent's deliberative self-control. Alternately, we can sever the connection between volitions and conscious self-control as Moore suggests, but I have argued that ends up making it quite mysterious why normative theory should care very much about volitions. Whatever interest volitions would have would be derivative from their role as instrumental to A's beliefs, desires, plans and so forth, but not as objects of legal or moral concern in their own right. ${ }^{21}$ In either case, the result is that it is at best misleading to suggest that a putatively fundamental principle of criminal responsibility is reasonably founded on a volitional theory of action.

What I take to be the important positive claim to emerge from the discussion so far is this: while a conscious mental state such as a plan or an intention is not necessary for criminal responsibility, insofar as we insist on the primacy of the act/non-act distinction, this is because of an intuitive connection between "acts" and conduct appropriately attributable to the agent. But the nature of this connection has yet to be clarified.

${ }^{20}$ Lectures on Jurisprudence, p.424.

${ }^{21}$ Perhaps it could be said that Moore only needs to show that every action is a volitionally caused bodily movement under some description; he does not need the further assumption that the legally relevant description of an action is that under which it is willed. I am agnostic as to whether every action in fact has some description under which it is a willed bodily movement, but I do think that something like the further assumption is critical to Moore's endeavor. For if it cannot be shown that the legally relevant description of an agent's conduct — the description which provides the basis for punishment-somehow rests on a description of that same conduct as willed bodily movement, then what would be the legal interest in having such a description? 


\section{2.}

Suppose that I am right that Moore's updated account of action as willed bodily movement is unhelpful for explaining Anglo-American criminal law's supposed act requirement. A natural reaction would be to cast about for an alternate theory of action to fit the bill. However, the conclusion I am after is more sweeping. What I shall argue is that there is no compelling reason to think our judgments of criminal responsibility are, or should be, held hostage to the theory of action in the way Moore suggests. (This is not to say that there might not be other ways in which the theory of mind or action might be relevant to criminal theory.) For “was X an action?” is simply not - as the act requirement suggests—a threshold question for "should we punish A for X?"

Two initial points must be emphasized. The first is that what I am challenging is the claim that the act requirement is a fundamental principle of criminal law; that is, as Antony Duff has noted, "to the familiar slogan that actus non facit reum nisi mens sit rea we can add the prior, more fundamental slogan that mens non facit reum nisi actus sit reus; before we ask whether a defendant acted with mens rea or fault, we must ask whether he committed a criminal act at all.",22 This claim implies that the act requirement cannot be a generalization from the sorts of crimes that Anglo-American law is, for various reasons, unwilling to accept. For in that case, it would be a mistake to think that X cannot be criminalized (or A punished for $\mathrm{X}$ ) because $\mathrm{X}$ is not an action; action would be, at best, a rough and ready shorthand for representing those things that are felt to be outside the scope of criminalization, though the substantive reasons why they fall beyond the pale may not have anything to do with

22 "Action, the Act Requirement and Criminal Liability," p.69. Duff is here describing the traditional view, not endorsing it. 
action per se. ${ }^{23}$ That $\mathrm{X}$ is not an action must be an independent reason for not criminalizing or assigning punishment on its basis, not merely a stand-in for other (and therefore, more fundamental) considerations; action should define not just the extension of the set of all crimes, but their intension as well. If the act requirement is a structural feature of the notion of criminal responsibility, it should be understood as an instance of what Rawls refers to as a "practice" rather than a "summary" based rule. ${ }^{24}$ Understood in this light, it is just as misguided to ask how many exceptions there are to the act requirement as it is to ask how many exceptions there are to the rule that solitaire is played by oneself. "Criminal responsibility requires an act" is, if valid, a constitutive feature of just punishment, not a statistical generalization. The claim that criminal responsibility "requires an act" should therefore be understood as an at least partial answer to theoretically ambitious question: what are the minimum necessary components of a morally acceptable concept of criminal responsibility? ? $^{25}$

Second, as noted above, there is a distinction between the act requirement as a restriction on legislation, decisions about whether to criminalize certain classes of conduct, and the act requirement as a restriction on judicial decision-making, decisions about whether to impose punishment on a given

\footnotetext{
${ }^{23}$ I do not mean to suggest that generalizations can never justify; obviously, they do in many cases. ("April is usually a rainy month in these parts; it is April; therefore, it is likely to be rainy.") The point is rather that as a bedrock normative principle regulating the distribution of punishment, the act requirement should furnish a moral reason that justifies the pattern of liability it produces rather than simply being a shorthand description of that pattern of liability.

${ }^{24}$ See Rawls, “Two Conceptions of Rules," 64 Philosophical Review 6 (1955), section III.

${ }^{25}$ See Simester, “On the So-called Requirement for Voluntary Action,” p.404.
} 
individual for a given crime. ${ }^{26}$ While these aspects of the act requirement are easily conflated, it is crucial to keep them distinct. When it comes to describing patterns of legislation, both as a de facto and as a de jure matter, the act requirement is at best a wildly inaccurate generalization from the various rationales that have been given against extending punishment to omissions, thoughts and statuses. It is only at the level of judicial decision-making that there is any indication that action is an independent explanatory variable. I agree there is a genuine and sound intuition that it is unjust to punish a person who was not in the appropriate way involved in the criminal result. But as I argue in the final section of the paper, that relation is best spelled out not in terms of action, but in terms of practically rational agency. ${ }^{27}$

I start by noting that if there is a moral reason to only impose criminal punishment for a person's acts, then standard types of non-action based liability-notably, omissions, thoughts and statuses — will at most be only very exceptionally permissible. The problem is that it is widely accepted that Anglo-American law in fact does criminalize various sorts of non-actions, and properly so. For instance, one can be criminally responsible for failing to pay taxes, to stop at a red light, to care for one's minor child, to take suitable care in one's risk-imposing activities, for conspiring to ${ }^{26}$ See Hart, "Legal Responsibility and Excuses," reprinted in Punishment and Responsibility, p.39, and John Rawls, “Two Concepts of Rules.”

${ }^{27}$ The act requirement has not uniformly been understood as a principle rather than a generalization. (See for instance, Glanville Williams, Criminal Law: the General Part, $2^{\text {nd }}$ ed. [London: Stevens \& Sons, 1961], p.13.) p.2.) But even when implicitly described as a generalization, it has nevertheless been claimed to have the role of a principle; in particular, as describing a necessary condition for responsibility. This vacillation is explained, in my view, by insufficient attention to the distinction between the role of the act requirement in its legislative and its judicial guises. 
commit a crime, for overstaying a visa and so on. Moreover, in some cases when actions are statutorily required, they are often at best only tangentially related to the object of punishment. ${ }^{28}$ And on one interpretation of the law of attempts, the object of punishment is the criminal intent, requiring the defendant to have taken steps towards its execution merely for evidentiary reasons. ${ }^{29}$ So a defender of the act requirement is now required to either explain away the apparent exceptions to the principle or show why it is wrong to have these crimes. I cannot think of any strategy for doing this that is convincing.

First, one might try to finesse the question in this way: the act requirement is shorthand for the claim that we have reasons—-moral ones, perhaps, but in any case specially weighty ones—for demanding a person have acted before imposing punishment. But unlike requirements, reasons, while possibly weighty, are not generally peremptory and can in particular cases prove to be less weighty than countervailing reasons_ of morality, social policy, political expediency or whatever

${ }^{28}$ This is particularly the case in American federal criminal law. For Constitutional reasons, the overt action in federal crimes is usually hooked onto crossing a state line, use of the mails, etc., though what the person who is convicted under such a statute is being punished for is obviously not the act of crossing a state line or putting a letter in the mail. See e.g. Schmuck v. United States, 489 U.S. 705 (1988) (mailing element of mail fraud satisfied by a third party's mailing of used car title application forms to the state.)

${ }^{29}$ The literature on attempts is extensive. For a start, see Whybrow, 35 Crim. App. 141 (1951) (per Lord Goddard, C.J.), Duff, “Action, the Act Requirement and Criminal Liability,” p.72; Husak, The Philosophy of Criminal Law, pp.95-6; Larry Alexander and Kimberly Kessler, "Mens Rea and Inchoate Crimes," 87 J. Crim. L. \& Criminology 1138 (1997); and Herbert Wechsler, William Kenneth Jones and Harold L. Korn, “The Treatment of Inchoate Crimes in the Model Penal Code of the American Law Institute: Attempt, Solicitation and Conspiracy,” 61 Colum.L.Rev. 571 (1961). 
else. Thus, exceptions to the act requirement are consistent with action as a rational restriction on criminal responsibility, for all the "act requirement" means is that there is a prima facie but defeasible case against criminalizing $\mathrm{X}$ when $\mathrm{X}$ is not an action (under some preferred theory of action.) This move would allow a defender of the act requirement to contest the idea that the existence of exceptions shows that the act requirement is not a genuine general normative constraint.

This is perhaps a step in the right direction, but I do not think it saves the traditional view. For when we do impose punishment for omissions, say, we do not do so with a sense that we are sacrificing one value for another. But since it is not as if, in being outweighed by other considerations, a reason ceases to be a reason, we should expect that the absence of an action still provides some normative force even in cases where the act requirement is trumped by other considerations. Yet this does not appear to be the case. It is dubious that we generally feel that while it is morally objectionable to punish a tax evader (who committed no act), unfortunately that reason is outweighed by the even more objectionable alternative of allowing tax evaders to go unpunished, a result which leads us to punish them while regretting it all the while. Another case in which AngloAmerican law imposes particular duties of care is that between parents and minor children such that a parent can be liable for failing to feed his child. There does not seem to be any appreciable sense in which the fact of the parent's inaction presents any exculpatory reason, even one that is ultimately outweighed. Indeed, we blame him precisely on account of his failure to act. Contrast these sorts of cases with punishing an offender more severely than previous, similarly situated offenders in order to "send a message" to potential future miscreants. Here we do sacrifice one principle_-that of fairness, in the sense of treating like cases alike-to another, the promotion of socially acceptable behavior. Here, there is a legitimate sense that even if the circumstances justify us in doing so, we do not act fully justly as regards the person whom we use to send our penal message. There is a sense of moral residue in this case that is not present in the case of the criminally negligent parent. The lack 
of moral residue in cases where we impose punishment for omissions suggests that these are not cases in which one moral principle is trumped by another.

Another line of attack is to try to re-characterize the problematic cases of what appear to be non-action based criminal liability as actually action-based after all. One way of doing this, at least for omissions, is to insist that some omissions are in fact disguised actions. For, it might be claimed, there is a difference between a person who "omits" to pay her taxes because of her principled political views and the person who is simply forgetful. The former deliberately omits while the latter merely fails to act. ${ }^{30}$ Perhaps, if we agree that bodily movement is not, as such, crucial in defining action, then willed omissions can also be classified as a kind of action, and therefore punishment on that basis is consistent with the act requirement.

The problem with this proposal is that not every criminal omission is a deliberate omission. Mere failure to act is sufficient, as for instance if a worker forgets to secure heavy machinery which then falls upon and kills passerby, or if a parent forgets his child in the backseat of his car on a hot summer day while he spends the day running errands. ("I forgot" is not generally a legally recognized excuse.) As these examples suggest, if mere failure to act were not properly subject to criminal penalty, then negligence, often premised on an agent's failure to do $\mathrm{X}$ as an ordinary standard of care requires, would be seriously curtailed as a basis for criminal liability insofar as it often rests on a non-deliberate failure to take certain required steps. Moreover, this proposal would effectively define an actus reus in terms of mens rea terms because it would distinguish omissions from failures to act on the basis of criminal purposes, i.e., whether the agent failed to do X purposefully or knowingly. This strategy makes hash of what I described earlier as the systematic ambitions for

${ }^{30}$ This distinction, it should be noted, does not accord with the Model Penal Code. MPC \$2.01(1) conditions liability on "a voluntary act or the omission to perform an act of which he is physically capable," and \$1.13(4) defines an omission as a "failure to act." 
separating out actus reus as an independent principle of criminal law, one which can exculpate even if every mens rea requirement is satisfied (or if there are none, as with strict liability.) ${ }^{31}$

A third, and initially more promising, way of trying to rescue the act requirement is by insisting that even in cases where it appears a person is being punished for a failure to act, in fact his punishment is predicated on previous acts which create an obligation that he later fails to meet through his omission/failure to act. ${ }^{32}$ For instance, a person who is charged with running a red light has a positive duty — given the undisputed act of getting in the car and driving — to obey traffic signals, or a person who has earned income in a jurisdiction has a duty to pay taxes on that income,

${ }^{31}$ A similar problem arises in the context of possession. The Model Penal Code simply defines the problem away in its general statute on voluntary action: "possession is an act, within the meaning of this Section, if the possessor knowingly procured or received the thing possessed or was aware of his control thereof for a sufficient period to have been able to terminate his possession." MPC $\$ 2.01(4)$. The "act" of possession, defined by reference to mens rea standards, is no longer "indifferent" in Holmes' sense. The strategy is of course legally sufficient, but wildly unconvincing on the merits, since knowingly receiving $\mathrm{X}$ and/or having the ability to divest oneself of $\mathrm{X}$ is in no way plausibly construed as a "bodily movement whether voluntary or involuntary," as the Model Penal Code defines an act. See MPC $\$ 1.13(2)$. The comment to $\$ 2.01$ suggests that possession be dealt with as an application of prior acts analysis, discussed below; see Comment to MPC §2.01, p.224. For further discussion, see Markus Dirk Dubber, "Policing Possession: the War on Crime and the End of Criminal Law," 91 J. Crim. L. \& Criminology 829 (2001), and Fletcher, Rethinking Criminal Law, pp.197ff..

${ }^{32}$ See Comment to MPC $\S 2.01$, p.217. 
and so forth. The object of responsibility is the complex of the prior act plus later omission/failure to act. $^{33}$

Such a construction raises difficult — though perhaps not impossible-issues as regards the limits on the stretch of conduct in which the act must take place and, crucially, how the background act must be "related" to the triggering non-act (i.e., what it means for an act to be "included" in the conduct for which the person is being punished.) One problem in this vein is that even if the general strategy is sound, it is at best quite incomplete. For the strategy of relating criminally culpable omissions back to prior acts does not even work for every kind of omission. Some jurisdictions, for

${ }^{33}$ Sometimes it is suggested that the prior act must be a culpable act. Glanville Williams writes, "when an act seems at first sight to be lacking it is sometimes possible for the court to look critically back through the accused's past until a culpable act is discovered." (Criminal Law: the General Part, p.13.) Williams' example is of a robber whose gun goes off accidentally, thereby killing his victim: the culpable act "is not the act of pressing the trigger (which, in this instance, is absent) but the act of presenting the gun, which brings the case within the law of implied or constructive malice in murder." (Ibid.) (Williams rightly points out that the availability of such a maneuver means that the act requirement is of “comparative unimportance.”) Williams' account faces difficulties in explaining why the robber should be punished for the shooting at all, if the only legitimate object of criminal responsibility is the prior act of presenting the gun; or why every armed robbery is not equally "within the law of implied or constructive malice in murder." The Model Penal Code takes an arguably broader line than Williams in requiring not a prior culpable act, but simply "conduct which includes a voluntary act or the omission to perform an act of which he is physically capable.” \$2.01(1) (my emphasis). Since not every criminally culpable non-act is premised on a prior culpable act (failure to pay taxes, etc.), the Model Penal Code version is of broader appeal for our purposes. 
instance, attach criminal penalties to failure to vote in an election. ${ }^{34}$ In the United States, failure of male citizens between 18 and 25 years of age to register with the Selective Service can (in principle) result in both serious fines and imprisonment. ${ }^{35}$ Such statutes present legal duties to act which are not conditioned on any prior act, even that of "entering" the jurisdiction. (One can be born into it, and simply fail to leave.) While the wisdom of such statutes is not uncontested, they are not contested on grounds that the sanctions they allow for are not conditioned on prior acts. So even if we allow that some instances of punishment for non-acts presuppose prior acts, it is simply not the case that every instance does so.

The important question, however, is not whether a technical means can be found to relate every instance of culpable conduct to some prior act, but whether doing so is illuminating. It is here that I think the more critical problems for prior acts analysis emerge. While it is true that one cannot be liable for failing to stop at a red light unless one has gotten into the car to drive in the first place, or be liable for paying income taxes unless one has earned an income, it is misleading to suggest that what one is being punished for in such cases in some substantive sense "includes" these previous acts. For it is not as if driving a vehicle or earning an income themselves contribute to the blame attributed to the criminal agent. It is true that the agent would not have the particular duty in question were it not for some previous voluntary act on his part, but the offense, and the blame and penalty that go along with it, consists in violation of the duty itself, regardless of what explains why

\footnotetext{
${ }^{34}$ Australia is the most notable example in the Anglo-American legal tradition. See Commonwealth Electoral Act 1924, esp. \$12. It is not entirely unknown in the United States: Georgia’s 1777

Constitution, Article XII, penalized failure to vote with a monetary fine.

${ }^{35}$ Military Selective Service Act $\$ 462($ a). To my knowledge, however, there have been no prosecutions for failure to register since the 1980's.
} 
he has the duty. ${ }^{36}$ Indeed, even by her own lights, a defender of the act requirement must insist on this point. For consider the alternative: if all the legal conditions on the acquisition of a legal duty are rolled into the offense of violating that duty, then since presence in a jurisdiction when the crime was committed is typically a precondition for acquiring a duty to comply with the criminal law of that jurisdiction, it follows that a person who commits any crime will be punished, in part, "for" his mere presence in that jurisdiction. But mere presence in a jurisdiction is not an act at all. Those who insist that just punishment can only be punishment for acts thus have no option but to deny that presence in a jurisdiction comprises part of the object of punishment. But if so, then what distinguishes the fact of having gotten into the driver's seat of the car or having earned an income as prerequisites to legal duties from being within the statute's jurisdictional purview? The "agent A would not have duty D unless precondition P obtains" test does not on its face distinguish those preconditions which are acts from those which are not, and it is not clear that there are any principled and non-circular grounds for doing so. Of course, one could insist that only those legal preconditions which are voluntary acts form "part" of the object of punishment when accompanied by a later culpable omission, but this would be ad hoc. Therefore, since both act and non-act preconditions exist, without an explanation of why one is salient and the other not, this test is useless as a defense of the act requirement. ${ }^{37}$

Our attempts to defend the proposition that criminal liability requires an act at the legislative level have not been fruitful. Since we have been stymied in our attempts to make good on the notion ${ }^{36}$ For further, and very useful, discussion of the distinction between punishing "for" an act, and punishing for conduct which merely "includes" an act (and some similarly skeptical remarks), see Husak, "Rethinking the Act Requirement."

${ }^{37}$ My thanks to Joshua Dressler and an anonymous referee for pushing me to clarify my thoughts in the preceding four paragraphs. 
that, from the legislative point of view, just punishment is always for an act, I tentatively conclude that that the principle should be abandoned. Acts are indeed the normal objects of criminalization, but the content of the assertion that, criminal responsibility requires an act is exhausted by the familiar and heterogeneous reasons against criminalizing omissions, thoughts and statuses—reasons which have everything to do with autonomy, privacy and discriminatory abuse, and nothing in particular to do with action as such. ${ }^{38}$ Thus understood, from the legislative point of view, the act requirement is wholly derivative. It is therefore not a fundamental principle of Anglo-American criminal law, for it is not a self-standing principle at all.

\section{3.}

I admit that it would be more than a little surprising if the consistent and long-standing consensus concerning the act requirement rested on a persistent illusion. In this section, I argue that there is a sound intuition underlying the act requirement, but that this intuition only has traction in its judicial rather than legislative role; and that it is better understood in terms of practically rational agency rather than in terms of acts.

The intuition is brought to mind by paradigm cases such as Martin v. State, in which the police carried the intoxicated defendant out of his home and onto the street, at which point he was arrested

\footnotetext{
${ }^{38}$ Though see George Fletcher, “On the Moral Irrelevance of Bodily Movements,” 143 U.Pa.L.Rev. 1443 (1994) for important qualifications on these standard arguments against omission, thought and status.
} 
for public drunkenness. ${ }^{39}$ The injustice of a subsequent conviction rests, I take it, on the thought that "he didn't do anything!" It is irrelevant whether public drunkenness can be perfected with no showing of mens rea, for the issue is more fundamental than that. So it does not matter to this thought whether liability for public drunkenness is "strict." On the other hand, it is important that Martin was physically carried onto the street rather than, say, being commanded to walk to the street. For in the latter instance, though punishment would still be unjust, it would be unjust because Martin was improperly coerced into going into a public space by the police, not because he did not "do" anything. In both cases, the conduct with which Martin is charged could be described as “involuntary," but for quite different reasons. Anglo-American criminal doctrine respects this difference by distinguishing the "act requirement" as an element of the crime from excuses (such as duress) as affirmative defenses. ${ }^{40}$ My argument so far has been that the development of this line of thought exclusively in terms of positive action is superficially plausible but ultimately cannot account for the great diversity in kinds and instances of justified criminal punishment. Keeping in view the diverse bases for just punishment, as well as the act requirement's doctrinal role as distinct from both the mens rea and excuse doctrines, how then best to unpack the basis for our judgment in cases like Martin or Larsonneur?

3931 Ala.App. 334, 17 So.2d 427. See also the infamous British case, Larsonneur, (1933) 24 Cr.App.R. 74, in which a French national was charged with being found in Britain illegally when the only reason she was "found" there was because she had been carried there by the police.

${ }^{40}$ It is thus somewhat misleading to say, as an account of the act requirement, that "a person is morally responsible for an outcome unless the occurrence of that outcome is involuntary vis-à-vis that person." (Simester, "On the So-called Requirement for Voluntary Action,” p.406.) For the sort of involuntariness in consideration is a more basic failure of agency altogether than the involuntariness of a person who acts in the shadow of a threat. 
The central concept is evidently something akin to an agent's ability to comply with the law he is charged with violating; that is, whether he was in a position to do (or refrain from doing) what the law requires. The paradigmatic cases of actus reus defenses - the person who is physically carried from one location to another, who has a seizure, sleepwalks and so forth-are cases in which the person was in no position to comply with the law's demands. Conversely, the problematic cases for the act-based theorist - the citizen who refuses to pay his taxes, who forgets to register for the draft, who fails to take reasonable precautions in his dangerous activities and the attempter who has decided to carry out some crime-are united in the fact that in each case the agent was in a position to comply with the law's demands, but did not do so. ${ }^{41}$

${ }^{41}$ Thus, several theorists have suggested that what is really at issue is not the act itself, but the voluntariness of that act. P.F. Fitzgerald, writing contemporaneously with Hart, suggested that the underlying rationale behind the act requirement is that we should not punish involuntary acts, and that the reason for this is that, "without inquiring too deeply into the moral justification for punishment, we may recognize the existence of a moral principle that we should not blame or punish one who could not help doing what he did." ("Voluntary and Involuntary Acts," p.18) Simester sounds a similar note when he writes that the "foundation of moral responsibility is not action but voluntariness; or, strictly, the absence of involuntariness." ("On the So-called Requirement for Voluntary Action,” p.411.) Douglas Husak, in contrast, has explicated the intuition not in terms of voluntariness per se, but in terms of a person's control over a state of affairs. Husak has long been explicit in his dissatisfaction with the act requirement, and has defended the claim that an agent's control over a resulting state of affairs better tracks our considered moral judgments regarding when it is appropriate to hold someone criminally responsible. In Husak's view, “a person lacks responsibility for those states of affairs he or she is unable to prevent from taking place or obtaining." Therefore, Husak contends, "control is more plausibly regarded as a condition of both 
We must, however, take some care in how we understand the notion of compliance in this context. For there are problems lurking in the wings: control over what? What degree of control, and how far to individualize our assessments of control? In what does control or voluntariness consist - what (if anything) unifies the various legally recognized forms of involuntariness? Does the agent who fails to carry out an affirmative duty "choose" to break the law? (When?) Why should it matter that the agent "could not have done otherwise" if he did what he wanted and intended to do all along? The remainder of this paper is devoted to sketching how to preserve what is sound in the so-called act requirement while suggesting answers to at least some of these questions.

More specifically, I think we can go a good distance in unpacking the underlying intuition if we ask: was X (the criminal state of affairs the defendant is charged with) caused or constituted by the agent's conduct qua practically rational agent? Or, in assertoric form: punishment is unjust unless the crime charged was caused or constituted by the agent's conduct qua practically rational agent. I believe that the practical agency condition, as I shall call it, captures what cases like Martin and Larsonneur have in common with cases involving seizure, automatic reflex and the like. The practical agency condition isolates the fundamental sort of defect involved in such cases from those more properly treated under excuse doctrines, and manages to do so without suggesting, implausibly, that positive acts are the only proper basis of liability —all while retaining the traditional independence (such as it is) of actus reus from mens rea doctrine.

moral and criminal responsibility." ("Does Criminal Liability Require an Act?", p.77) Finally, Michael Corrado defends the view that "there is indeed a voluntary act requirement, and ... the essence of it is that the actor must have been able to avoid choosing to break the law. She must have been able to control her choice." ("Is There an Act Requirement in the Criminal Law?”, 142 U.Pa.L.Rev. 1529, 1557 (1994)) 
The central question for the practical agency condition is to explain what notion of practical agency is being appealed to. As a first gloss, what I suggest is the common-sensical interpretation that a practically rational agent is an agent who is in a position to guide his conduct through the normal use of his deliberative and executive capacities - that is, those capacities for forming and acting on intentions. ${ }^{42}$ An understanding of practical agency in these relatively vague terms is enough, I think, to show why the agent who is under extreme emotional stress (the standard example is walking in on a philandering lover), as with the agent who is threatened with harm unless he does X, cannot make use of the "act requirement" to exempt himself from liability, whereas the epileptic or unconscious agent (who may "do" exactly the same things) can. For the provoked agent is still an agent in the sense of forming and acting on intentions; his problem is rather that his judgment concerning what he ought to do in his situation is impaired. However, that defect, serious as it is, does not implicate his ability to form and act on intentions just as such. Invocation of the practical agency condition would require A to show not just that his grasp of which reasons to act on was impaired, but that his ability to grasp and act on reasons at all was destroyed; and that is both significantly rarer and harder to show. ${ }^{43}$ Similarly, we should not deny that the individual who acts

${ }^{42}$ Is practical reasoning broadly speaking "cognitive"? Are the conclusions of practical reasoning themselves motivating, or do they require supplementation by desire or some other kind of "proattitude"? Or are the conclusions of practical reasoning the actions themselves? While these issues (and others) are central to the contemporary philosophical debate about practical rationality, I am cautiously optimistic that the practical agency condition does not presuppose any particular theory of practical rationality, at least so long as that theory allows us to describe agents as considering and selecting among alternatives, and acting on the basis of those decisions.

${ }^{43}$ I do not mean to suggest that one can necessarily draw a sharp distinction between judgment and agency; indeed, I find such a suggestion rather implausible. But even if certain kinds of judgment are 
because he is threatened with grave harm is still an agent, and indeed, that he is the cause of the harm in question. Given sufficient coercion, he should be exculpated under the heading of duress, but not exculpated because he is no longer a practically rational agent. (There would, after all, be little point in trying to coerce such an individual.) In contrast, if we suppose that an epileptic seizure removes any ability to control one's motions, then nothing requiring such a motion would be available to one in the grip of a seizure; one would, in that respect, no longer be a practically rational agent. The harm such an agent unequivocally causes is therefore not caused or constituted by his conduct as a practically rational agent.

As an aside, the focus on practically rational agency rather than control has an advantage here, in that the ability to control one's conduct is not evenly distributed in the population, and it is a fine question as to "how much" control (however we measure it) is enough in a given situation to allow a prosecution to proceed. Are extreme neurotics, the habitually impulsive, and the congenitally weakwilled-all of whom plausibly are less able than the average person to control themselves in various situations - therefore less prosecutable than the average person? (The neurotic who can't make up his mind to register for the draft, the impulsive grab for easy money, the follower who gets talked into a criminal plot, etc..) Now to be sure, the ability to form and act on intentions is also a variable trait, but the baseline below which a person has to fall to fail this condition is both lower and more discernible than what is suggested by the control criterion.

intrinsically action-motivating (and thus do not need supplementation by a further "pro-attitude"), the distinction I am drawing can nonetheless still be made out; for it is the distinction between a defect in the person's grasp of reasons leading to his forming bad action-motivating judgments, and a person not being in a position to form such judgments in the first place. 
A somewhat more difficult case for the practical agency condition is Anglo-American criminal law's excusal of crimes committed while sleepwalking, under hypnotic control and the like. ${ }^{44}$ The difficulty here arises when we note (as Bernard Williams and others have pointed out), that there is an "intentional contour" to the actions of the sleepwalking or hypnotized agent, and it is accordingly difficult to assimilate such individuals to the epileptic or the comatose or the physically constrained as "non-agents." 45 Yet, unlike the enraged lover, we want to excuse individuals for crimes committed while sleepwalking, etc., and excuse them precisely because their will is in some sense not implicated in the crimes they commit. Like the epileptic, we imagine such agents to be in an important way dissociated from the movements of their bodies. But like the enraged lover, their conduct is clearly intentional. Tentatively, I suggest that while such agents do act intentionally, they nonetheless are excused because they fail to be practically rational agents insofar as they do not have, one might say, executive self-control. In other words, we conceive of such agents as being in some way

\footnotetext{
${ }^{44}$ See MPC \$2.01(b) and (c). See also People v. Newton, 8 Cal.App.3d 359 (1970) (appealing conviction on basis of automatism as a reflex response), Fulcher v. State, 633 P.2d 142 (Wyo. 1981), (appealing conviction on basis of unconsciousness), People v. Higgins, 5 N.Y.2d 607 (1959) (appealing conviction on basis of seizure-induced conduct) and Michael Corrado, "Automatism and the Theory of Action,” 39 Emory L.J. 1191 (1990) (developing incompatiblist theory of voluntariness for the criminal law).

45 “'The agent may be asleep, yet the language, not just of action, but of purposive action, be appropriate beyond dispute." "Voluntary Acts and Responsible Agents," 10 Oxford J. Legal Stud. 1 (1990). See also Williams’ paper, “The Actus Reus of Dr. Caligari,” 142 U.Pa.L.Rev. 1661, 1663 (1994), in response to the "metaphorical" theory Moore develops in Act and Crime.
} 
commandeered, as having their agendas set by something or someone else. ${ }^{46}$ So while the steps they take in carrying out those agendas are surely not unintentional, they are nonetheless not intended by the agents as part of some plan for which they are responsible. The radical dissociation between the agent's sense of self and the relevant conduct calls into question these agent's ability to set their own ends, as opposed to merely finding efficient means of carrying out extrinsically given ones; and this may call into question whether such individuals can be seen as practically rational agents such that prosecuting them for harms they commit while in that state is justified. Of course, there are likely to be very close cases, and a great likelihood of self-serving dissimulation. And just as obviously, the notion of executive control on which I am relying, as well as the degree to which it can be distinguished from the means-end intentionality which characterizes the commandeered agents, require much further elaboration. ${ }^{47}$ Fortunately, while the conceptual issues are murky and deep, such cases arise only infrequently in actual criminal contexts.

46 "Where there is evidence of the existence of that state of the mind wherein the individual's conscious mind has ceased to operate and his actions are controlled by the subconscious or subjective mind it would be error to refuse instructions as to the legal effect of such unconsciousness." People v. Sameniego 118 Cal.App. 165, 173 (1931).

${ }^{47}$ Perhaps a start—but only a start—would be to unpack executive control in terms of the motivations for a person's actions. They must be, one is tempted to say, one's own reasons and/or desires: that is, they must be motivating because one has judged them to be worth pursuing. For one development very roughly along these lines, see Richard Moran, Authority and Estrangement: an Essay on Self-Knowledge (Princeton: Princeton University Press, 2001). See also Harry Frankfurt, "Freedom of the Will and the Concept of a Person," 68 Journal of Philosophy 5 (1971). It is also not, at least in the realm of the law, a purely philosophical inquiry; there are empirical questions about how well we 
Before turning to address objections, I want to point out two further comparative advantages of the practical agency condition over alternate accounts in the literature. First, the practical agency condition has particular appeal when dealing with the "culpability-in-causing" cases, in which a person's involuntary conduct causes harm, but his involuntariness is a result of his own doing. The paradigm case is People v. Decina, in which Decina knew he was prone to epileptic seizures yet failed to take his medication before driving and, as a result, had a seizure behind the wheel and thereby killed several children. ${ }^{48}$ The challenge these cases pose is that while Decina was clearly culpable, not every epileptic driver is-for instance, a person who has no reason to suspect she is epileptic when she has a seizure behind the wheel. I agree with the received view that what is important is that Decina knew of his susceptibility to seizure, and knew that he ought to take his anti-seizure medication prior to driving. Where I disagree is that I do not view these facts as important because they establish some kind of nexus between Decina's causing of the deaths and a prior culpable act, a nexus which is necessary for punishment to be permissible, for I do not view it as important that there be a prior act at all. ${ }^{49}$ Nor does the practical agency condition need to be given an ad hoc qualification to address these cases ("X is required for criminal responsibility, except when ...")—a result that would seemingly be at odds with the supposedly fundamental character of the condition. understand shock, automatism, somnambulism and the like, and what sorts of rational self-guiding capacities agents so afflicted are likely to have.

${ }^{48} 2$ N.Y.2d 133 (1956). See also Fulcher v. State, 633 P.2d 142 (Wyo. 1981). It is cases like Decina that motivate the prior acts analysis discussed in section 2.

${ }^{49}$ Suppose that Decina gets a peculiar sensation in his temples exactly five minutes before he has a seizure, and that this sensation is a completely accurate predictor of his seizure. Now he is driving along; he notices the sensation; he fails to move his foot off the accelerator; as a consequence, etc.. I see no reason to suppose that the result should be any different in this case than in the actual case. 
Rather, the practical agency condition directly allows prosecution in cases like Decina because, given the defendant's knowledge of his condition, his deciding to drive without the anti-seizure medication itself amounts to conduct as a practically rational agent which causes the harm with which he is charged. Thus, on the practical agency condition, we can easily accommodate culpability-in-causing cases without modifying the supposedly general norms of criminal responsibility through ad hoc qualifications or tortured and under-inclusive "prior acts" analysis. ${ }^{50}$

Second, the practical agency condition has the advantage that, as compared to the control and voluntariness criteria, it is philosophically less contentious. Those criteria rest crucially on the premise that a person is not responsible if he could not have done otherwise; or, in Husak's case, if he could not have prevented the state of affairs from taking place or obtaining. ${ }^{51}$ But this premise (in either version) is philosophically vulnerable; and indeed, is the subject of quite a bit of on-going controversy. ${ }^{52}$ The practical agency condition is not so committed, and thus raises fewer philosophical difficulties. For consider: interpreted on its face, Husak's control requirement would ${ }^{50}$ The practical agency condition also has the doctrinal advantage of dealing more consistently with possession crimes than the Model Penal Code's somewhat ad hoc definition-required by their reliance on voluntary acts.

51 “Does Criminal Liability Require an Act?”, p.77.

${ }^{52}$ The debate took off with Harry Frankfurt's paper, “Alternate Possibilities and Moral Responsibility," in 66 Journal of Philosophy 829 (1969). Since then, an extremely productive cottage industry has sprung up debating these issues. For discussion and further references, see John Martin Fischer, "Recent Work on Moral Responsibility," 110 Ethics (1999), pp.93-139; Ken Levy, "Why It Is Sometimes Fair to Blame Agents For Unavoidable Actions and Omissions," 42 American Philosophical Quarterly (2005), pp.93-104; and the essays in Moral Responsibility and Alternative Possibilities, ed. David Widerker and Michael McKenna (Hants: Ashgate, 2003). 
exonerate any agent when the harm he causes is over-determined, i.e., if there exists a causal force independent of the agent sufficient to bring about the state of affairs in question. Thus, if $\mathrm{A}$ has decided to murder B by putting poison in his glass, then normally A would be liable given his control over whether B is poisoned. But now suppose that $C$, acting independently of $A$, has also decided to murder B by putting poison in his glass; indeed, suppose $\mathrm{A}$ and $\mathrm{C}$ put equal dosages of the same poison into B's glass, each of which is sufficient to kill B. Strictly speaking, A has no control over whether B dies, or even over whether B is murdered, since no matter what A does, C will cause $\mathrm{B}$ to be poisoned. Moreover, since $\mathrm{C}$ can raise the same defense as $\mathrm{A}$, the control requirement thus interpreted would entail that neither is responsible for B's murder, clearly an absurd result.

Husak can retrench and claim that the control requirement is not just a matter of what is controlled (states of affairs), but also over how it is controlled (with or without the agent's participation). Retrenching along these lines brings Husak's views closer to that of Fitzgerald and Simester, that what is required for (legal) responsibility is the ability to have done otherwise. (Following standard terminology, we can call this the principle of alternate possibilities.) But the problem of over-determination is not escaped quite so easily. For the agent's participation in the result can also be over-determined, as Harry Frankfurt's famous examples are meant to indicate. Briefly, suppose A wants to poison B, and he is considering whether he shall. Now suppose that an evil demon, mad brain scientist or rare neurological disorder lurks, ready to flip a switch and cause A to decide to poison $\mathrm{B}$, should $\mathrm{A}$ indicate (perhaps through certain neurological signs) that he is about to decide to do otherwise. But $\mathrm{A}$ in fact decides to poison $\mathrm{B}$, and proceeds to do so of his own accord. Given the circumstances, $\mathrm{A}$ in fact has no control over either the resulting state of affairs or his participation in it. But since the reason A poisons B is not because he is forced to do so by the evil demon, et al, but rather because of his own decision, it seems gratuitous to exculpate A 
on grounds of a lack of control. Thus, if the example is sound, then the claim that responsibility requires the possibility of doing otherwise is seriously jeopardized. Put in more general terms, A may be responsible for $\mathrm{X}$ if A's lack of control with respect to $\mathrm{X}$ does not contribute to explaining why A $\operatorname{did} \mathrm{X}^{53}$

Such a cursory sketch does not, of course, amount to an argument against the principle of alternate possibilities, and so does not directly undermine Husak's control requirement. However, my claim is that if we retreat from control as ability to influence outcomes to control as ability to have done otherwise, we are inescapably premising an account of when imposing criminal punishment is just on the resolution of on-going and potentially intractable philosophical issues. Since the practical agency condition does not presuppose the principle of alternate possibilities, it is not troubled by Frankfurt-type examples, and thus, I think, less hangs on the outcome of that debate for the practical agency condition than for the control requirement. The background assumption to my argument here is the belief that it overburdens criminal theory to suppose that basic legal concepts such as actus reus cannot be adequately understood until the problems of perennial philosophy are ultimately resolved. If we can avoid having to say that, we should; and I think the practical agency condition shows us how, in this one context, we can. ${ }^{54}$

It might be objected that, since the principle of alternate possibilities says that such possibilities are necessary for moral responsibility, an account of (in this case, legal) responsibility that does not ${ }^{53}$ See Fischer, "Recent Work on Moral Responsibility," pp.109ff. for a much more detailed discussion of the inner workings of Frankfurt-type examples. I note that the status of these examples remains hotly contested.

${ }^{54}$ Ken Levy, in personal discussion, has suggested that it may be possible to develop an account of control that does not presuppose the principle of alternate possibilities. If so, that would put the control requirement on a similar footing as the practical agency condition. 
require such possibilities is not agnostic on the principle; it rejects it. But if that is so, then the same should apply and the dialectical advantage of the practical agency condition (beyond simply providing a broadly compatiblist alternative) over the control requirement evaporates. The response to this challenge is that the practical agency condition in fact is agnostic. After all, it can be given an interpretation that is consistent with the principle of alternate possibilities, for instance, by arguing that if A's decision to do X was causally determined such that it is not true that A could have formed and acted on an intention to do not- $\mathrm{X}$ instead of $\mathrm{X}$ at the relevant time, then A's conduct was not in any meaningful sense guided by his deliberation as to what to do, and so A fails to be a practically rational agent in the relevant instance. ${ }^{55}$ Of course, one could also insist that the principle of alternate possibilities is wrong-headed, in which case it would be no argument against the practical agency condition that it does not yield a pattern of responsibility consistent with that principle. By leaving the notion of practical agency at a higher level of abstraction, the condition is not ipso facto committed to either a compatibilist or an incompatibilist reading, but remains—or so I hopesufficiently substantive to provide principled guidance in deciding cases.

I conclude by considering three objections.

First, it might be objected that the practical agency condition requires that criminal responsibility be premised on intentional—in the sense of deliberate—conduct. But this is misleading, for failure to act, including negligent failures, are all properly subject to criminal sanction. In response, while I accept the major premise of the objection, I reject the conclusion, as I think failures to act indeed do fall within the scope of the practical agency condition. After all, the

\footnotetext{
${ }^{55}$ Corrado may adopt a view along these lines when he defends the necessity of "voluntary choice" rather than "control" as an interpretation of the act requirement. See his paper, "Is There an Act Requirement in the Criminal Law?"
} 
harms complained of (failing to register for the draft, imposing risk by failing to secure heavy machinery) are in fact caused by the individual's conduct during a legally relevant stretch of time. That is, it is sufficient to bring about these harms that at no point during the relevant stretch of time did the agent undertake to do what was legally required. The practical agency condition is satisfied so long as, during that time, the individual was not causally prevented from taking stock of what he was failing to do, and taking steps to bring himself into compliance. (As, for instance, if the agent was in a persistent vegetative state during the entirety of the relevant timeframe.)

Second, one might reasonably ask: if $\mathrm{X}$ is a requirement on every case of justly imposed punishment, how could it not be an independent basis for restricting the definition of crimes? Surely, one might insist, there is a role for the practical agency condition in restricting the definition of crimes, since it restricts in every instance how such laws are applied. I concede that the condition could in theory be used, for instance, to prohibit crimes with which it is impossible to comply—e.g., if a legislature were, for some reason, to penalize being born on an odd-numbered day of the month, or to require a person to do something physically impossible. Such "offenses" would not be caused or constituted by the agent's conduct as a practically rational agent, and so would be unjust as such. I would not, however, expect this to be a very significant role for the practical agency condition in a reasonably well-ordered polity, especially in comparison to its role in restricting the application of facially just criminal laws.

Finally, one might challenge not the content of the practical agency condition, but its general applicability. It is, after all, certainly not obvious that the law must in every case treat its subjects as practically rational agents. That a person was not functioning as a rational agent at the time of the 
offense is not always a defense, for instance, in civil tort actions. ${ }^{56}$ So why condition criminal responsibility in general on it? I agree that nothing I have said so far provides an answer to such a fundamental challenge, for it is one thing to describe a possible moral constraint on criminal responsibility, and something else altogether to provide a justification for accepting that constraint in the first place. But answering such a sweeping challenge has not been my task; rather, I have proceeded by attempting to rationally reconstruct the intuition I take to underlie Anglo-American criminal law's "act requirement," and to do so in a way that preserves some role for it as a fundamental and independent limitation on when punishment is imposed. I think such a role is sensible, and makes moral sense, but I have not defended that claim here. Perhaps all that can be said here is that so long as we assume some distinctive role for the criminal law in expressing norms of moral condemnation and not simply — that is, not only-in the regulation of destructive behavior, then there is plausibility to the view that the criminal law should be concerned with individuals not just as brutely subject to the law's demands, but as rationally responsive to them as well. Obviously much more can be said on this point. My aim has been limited to the more modest task of rational reconstruction in criminal theory, not the laying of normative foundations.

The view I have sketched marks, in one sense, a radical departure from the orthodox view that criminal responsibility requires an act. For I have argued that, contrary to the usual understanding of the act requirement as an independent and fundamental principle of Anglo-American criminal law, whether $\mathrm{X}$ is an act is not a threshold question for whether it is permissible to criminalize $\mathrm{X}$, regardless of the content assigned to X. It may well be a bad idea to make a crime out of, say,

${ }^{56}$ See e.g., Breunig v. American Family Insurance Co., 45 Wis.2d 536, 173 N.W.2d 619 (Wis. 1970); and Restatement (Second) of Torts §283B and §895J (1979). 
deliberately omitting to register for the draft, forgetfully failing to feed one's child, being drunk in public, being in a country illegally, or failing to exercise due care in undertaking hazardous activities. But if such crimes are unjust or otherwise a bad idea, the explanation will not be: because these are iin some sense not genuine acts. However, in another and perhaps deeper sense, the view I have sketched is not a departure at all. For if I am right, the practical agency condition is a plausible interpretation of the intuition that an agent must be an author of that for which he is being held criminally responsible. And it is this intuition, I suggest, that has actually, if obscurely, motivated Anglo-American criminal theory's supposed "act requirement" all along. 